\title{
Transforming Turkish Universities to Entrepreneurial Universities for Sustainability: From Strategy to Practice
}

\author{
Sema Yılmaz Genç ${ }^{1}$, Harun Sesen ${ }^{2}$, Rui Alexandre Castanho ${ }^{3,4,5,6,7}$, , Dervis Kirikkaleli ${ }^{2, *}$ (D) \\ and Semih Soran ${ }^{8}$ \\ 1 Kocaeli Vocational School, Department of Marketing and Advertising, Kocaeli University, 41140 Kocaeli, \\ Turkey; semayilmazgenc@gmail.com \\ 2 Faculty of Economics and Administrative Sciences, European University of Lefke, 99780 Lefke, Turkey; \\ hsesen@eul.edu.tr \\ 3 Faculty of Applied Sciences, WSB University, 41-300 Dabrowa Górnicza, Poland; racastanho@uevora.pt \\ 4 Institute of Research on Territorial Governance and Inter-Organizational Cooperation, 41-300 Dabrowa \\ Górnicza, Poland \\ 5 Environmental Resources Analysis Research Group (ARAM), University of Extremadura, 06071 Badajoz, \\ Spain \\ 6 CITUR-Madeira-Centre for Tourism Research, Development and Innovation, 9000-082 Funchal-Madeira, \\ Portugal \\ 7 VALORIZA-Research Centre for Endogenous Resource Valorization, Polytechnic Institute of Portalegre (IPP), \\ 7300 Portalegre, Portugal \\ 8 Faculty of Aviation and Aeronautical Sciences, Ozyegin University, 34794 Istanbul, Turkey; \\ semih.soran@ozyegin.edu.tr \\ * Correspondence: dkirikkaleli@eul.edu.tr; Tel.: +90-5488637770
}

Received: 19 January 2020; Accepted: 16 February 2020; Published: 17 February 2020

\begin{abstract}
Today, universities are seen as the main actors of technological change, innovation, and social development; this situation causes new roles for universities, as well as forces them to change. At present, universities face very important expectations such as research and entrepreneurial activities by providing the industry-university cooperation along with education and training. In order to manage that transformation, it is seen that the universities across the world evolve to context of entrepreneurial university. Within this general framework, the main objective of this research is to determine where Turkish universities stand on the transformation of entrepreneurial university. In order to achieve this goal, 68 public universities' strategic plans, which are thought to reflect the intentions for the future, were subjected to content analysis. The findings showed that the majority of universities in our country did not have entrepreneurial university features but they have strong intention and desire for a transformation in this direction.
\end{abstract}

Keywords: entrepreneurship; entrepreneurial university; strategic plan; content analysis

\section{Introduction}

Universities are seen as the main actors and triggers that direct the technological change and innovation in today's information era. Many policy makers consider universities as the "information factories" of the new economy [1]. Such a perspective for the universities emphasizes the integration of universities with the region they are in and the commercialization of the information they produce [2]. However, although the intensive flow of information facilitates innovation, the transfer of this knowledge from university to industry is theoretically easy, but in practice, is a complex and enduring process. Thus, it is clear that universities need creative methods and solutions for transcending the 
classical teaching objectives of the past, transferring the information produced to the industry, and converting it into a commercial value [3].

Today, universities are considered to be important instruments of regional economic and social development as well as knowledge production [4]. Transformation of the information produced within the university into entrepreneurial activities or a university-based investment and getting a commercial value in the market by joint ventures with the industry, and having entrepreneurial graduates who trigger the economic development with regional initiatives and, at the end, emergence of an "entrepreneurial university" are some of the new roles assigned to universities in the new age [5].

Many authors see this transformation as a second evolution in universities [6-8]. In addition to education as a result of the first evolution, the universities, which assume the task of doing research, are facing the expectation of supporting economic and social development through entrepreneurial actions as a third task at the end of this second transformation [9].

Entrepreneurial university is defined in many different ways, like the university that uses new resources such as patents, contractual research, and collaboration with a private company $[10,11]$, the university that creates new jobs through its faculty, staff, or students [12], or universities based on both commercialization (training programs, consultancy services, and development activities) and objectification (patents, licenses, or new jobs established by students (alumni) [13]. The common aspect of all these definitions is that the entrepreneurial university points to a structure far beyond the roles of the ivory tower university [5].

While it is seen that universities in many parts of the world are evolving into entrepreneurial universities, it is a fact that efforts in this direction have accelerated in recent years in Turkish universities too. Some may think that there is no significant factor that forces the state universities in Turkey to become entrepreneurial universities since they mainly use government financial support [14], however it is not possible for Turkish higher education institutions, which have to compete in many international platforms, whether they are state or foundation universities, to remain indifferent to this transformation in the world. The increasing demands and pressures of government, local governments, and important stakeholders such as partners, students, parents, and industrialists on universities and the expectations of the universities to create marketable value for the society are undoubtedly forcing Turkish universities to evolve into entrepreneurial universities.

Within this frame, the main purpose of the research is to determine the intention of Turkish universities to graduate entrepreneurial individuals and to become entrepreneurial universities. The main objective of the research is to examine the strategic intentions of Turkish public universities on the transformation to entrepreneurial universities. The findings of this study may be helpful for other universities and/or higher education institutions on the way of a possible transformation to an entrepreneurial university. Also, the results of the research may be helpful for policy makers of higher education in different countries to understand the impacts of strategic planning and guidance for the way on entrepreneurial transformation. Within the scope of the research, the strategic plans of universities, which are indicative of their long-term intentions, were examined and achievement of the stated purpose was attempted. In this context, following the introduction, the topics of entrepreneurial universities, strategic planning in the universities, and sustainability of the universities were reviewed in the second chapter, and then the findings of the strategic plan analyses of the universities were presented.

\section{Evolution of Universities, Entrepreneurial University, and Sustainability of Universities}

Entrepreneurship is defined as "an innovative activity combining existing resources with the capacity to produce new wealth" [15], "the process of creating something new, resulting in personal satisfaction by spending the necessary time and effort" [16], or "managing the redistribution of economic resources" [17]. The authors of [18], on the other hand, see the entrepreneur as the person who applies new combinations in a way that disrupts continuity and Ref [19] describes the entrepreneur as "a person who sees profit opportunities and demonstrates an initiative to meet unsatisfied needs". Based on 
these definitions, we can divide the actors carrying out entrepreneurial actions into two large groups as entrepreneurial individuals at the micro level and institutional entrepreneur organizations at the macro level. In this context, entrepreneurial universities emerge as macro-level institutional entrepreneurial structures that carry out entrepreneurial actions, have external links, access to university resources, and conduct innovation and scientific research [20].

An entrepreneurial university is defined as a university capable of producing a strategic direction [21] focused on both the formulation of academic objectives and the transformation of knowledge produced within the university into economic and social benefit [7]. A university that establishes patent and/or entrepreneurship centers within the university, conducts innovative projects jointly with governmental institutions or private firms, conducts research and integrates with all social partners through research centers or technology parks [3,22], and offers opportunities and environments to encourage students' entrepreneurship [23] can be called an entrepreneurial university.

Ref [24], examining the birth of entrepreneurial universities, evaluates the developmental processes of universities in three periods: (1) Science-oriented university, (2) education- and research-based university, and (3) entrepreneurial and socially integrated university. Ref [25] examined the transformation process of universities around the world, and divided this transformation into three phases. They state that in the first period, when universities were established, the aim was science and learning; in the second term, the aim turned to research; and in the third term, the entrepreneurial universities emerged and commercially beneficial product was added to the research.

The birth of the third-term universities dates back to the 1960s. In this period, the developments in technology, especially in information technologies, started to force the second-period universities that did research only but did not share the results of these researches with the society or turn them into commercial value [26]. These universities, which have been seen especially in the U.S., have started to make joint researches with industrial institutions, have established companies, and started to turn the information they produce into commercial value. These universities, which are called entrepreneurial universities, force the structures of universities in all other countries to change [20].

Ref [7], examining the transformation process of Stanford University into an entrepreneurial university, states that the university first developed from a traditional university to a research university and then into an entrepreneurial university. According to the author, this transformation process first started with the organization of group research and creation of commercially worthy researches, and then was completed with the development of institutional mechanisms to carry out commercially worthy researches outside the institution and the integration of academic and non-academic units in a common framework [5]. This transformation of Stanford, which began at the beginning of the 20th century, changed the city of San Francisco where it is located. Formerly a port, trade, and financial center, the city was transformed by Stanford after entrepreneurial actions of its graduates, first becoming electricity and then an electronic center, which in time created the miracle of "Silicon Valley" [27].

Research shows that there is no typical university model, nor is there a typical entrepreneurial university model [28]. However, when the institutions that have successfully transformed to the entrepreneurial university are examined, it is seen that the entrepreneurial university is basically an institution that has three characteristics [26]. These features can be listed as the university itself being an entrepreneur, the members of the university (faculty, students, and other employees) striving to become entrepreneurs, and interacting with the environment in which the university is located [20].

Ref [29] states that the entrepreneurial university should have three main objectives. First of all, the graduates of the university should be not only job seekers, but also job-creating individuals. This aim draws attention to the fact that the entrepreneurial university should educate entrepreneurial individuals. Secondly, it is stated that entrepreneurial management should be examined in multidisciplinary research groups in order to cope with the problems that arise during the establishment of new firms. Thirdly, it can be stated that the research carried out within the universities should be designed and implemented not only for academic publication, but also as a source of innovation for 
the national economy and society. In 1995, more than $61 \%$ of all basic research in the United States was conducted by universities [30].

The question at this point is whether the transformation of universities into entrepreneurial universities is a necessity. In fact, the answer to this question is largely hidden in the change experienced in the last decades. The economic, political, sociological, and technological changes experienced in these period force universities to change irreversibly. The most important problem posed by this pressure of change seems to be the inability of universities to meet the expectations of society and governments.

Ref [21] stresses four main sources of that pressure. First, the fact that more and more people in every segment of society are willing to continue higher education [21,31]. University education, which stood before as an elite teaching, is theoretically equal distance for everyone today and many people want to benefit from this teaching. In Turkey, the case is similar to the other parts of the world and the Council of Higher Education (CHE) of Turkey reports that while the total number of applicants for higher education in 1980 was 466,963, this number was 1,851,618 as of 2005 [32]. Demand for higher education has grown almost four-fold in the last 25 years. To meet this demand, many new universities were established; and the number of universities increased from 19 in 1981 to 165 in 2011 (103 of which are State Universities and 62 of them are foundation) [33]. As a matter of fact, the author in [33] states that the number of students envisaged by CHE of Turkey for the vision of 2025 has been reached as of 2011 as a result of the increase in the university quotas. This shows that the capacity limits of all universities are being challenged.

Secondly, both industry/business life and the graduates force universities to provide the necessary knowledge, skills, and abilities to graduates for professional life [21]. In addition, graduates' desire to continue post-graduate education, which they think will be useful in their professional careers, both transforms teaching into an endless process, and also eliminates the limits of the skills to be acquired in education, thus transforming education into a lifelong structure [31]. As a matter of fact, the figures in Turkey show that the number of people attending post-graduate education has increased in the last quarter century, and the number, which was 7983 in 1993, reached 27,469 in 2004 [32].

Thirdly, the dominant concept of "make it with lowest cost" suppresses the classical understanding of the university and forces the universities to look for additional funding sources [21]. This pressure transforms higher education from an elite structure to mass production. Governments' desire to make the maximum number of people part of higher education at the lowest cost forces the capacity of universities and puts them under pressure to transform. For the Turkish universities, the weight of the state budget decreased from $69 \%$ in 1995 to $57 \%$ in 2005 [32]. This naturally forces universities to create new sources of funding.

The fourth pressure is that the information available is more than the sources [21]. Today, no higher education institution or university is considered to have the capacity to control the development of knowledge on any subject by itself. In this context, there is a great race to take the lead in knowledge creation and this race extends beyond the boundaries of the university and attracts many institutions. Research institutions, industry, private sector, and public institutions continually produce new information; however, it is not possible for the universities to control or assimilate this new information. This creates a new perspective in knowledge management, suggesting that no one or institution in the international context can control the production, reformulation, and distribution of information by itself. It can be said that this is forcing universities to change and putting pressure on other channels of information to develop cooperation channels.

When reviewing the literature so far on the change and development of universities, it is thought that the transformation of universities towards entrepreneurial universities is a natural result of the development of universities. When the issue is evaluated in the Turkish context, it is considered that because of the powerful public support on funding, Turkish universities did not have a development process like in Europe or the USA. However, for surviving and competing internationally, it might be concluded that Turkish universities evolve towards the entrepreneurial university in the course of natural development. Thus, the main purpose of this research is to determine where the universities 
in Turkey are in the transformation to entrepreneurial universities. In order to achieve this goal, the strategic plans of the universities showing their long-term intentions have been examined.

\subsection{Strategic Planning and the Universities}

Strategy can be expressed as a perspective, a broad view, or a direction [34]. The strategy, as a successive integrative process, is a plan or model that combines the main objectives and policies of an organization [35], thus determining in which areas the organization should operate, with which means to reach targets, and with which behavioral patterns to use [36]. The direction of the organization, its objectives, and the means used to achieve its goals are the determinants of the strategy. Strategic management is a process in which the plans are analyzed in the process and the organization is directed to the desired point $[37,38]$.

In Turkey, the Public Financial Management and Control Law No. 5018 defines a strategic plan as "a plan that includes the medium and long-term objectives, basic principles and policies, objectives and priorities, performance criteria, methods to be followed and resource allocation of public administrations". Under the Law, with a few exceptions, all public institutions, including universities, are obliged to prepare a strategic plan and all public managers are required to prepare a strategic plan specific to their institutions.

The President's Office of Strategy and Planning (POSP) offers a strategic planning model for public institutions. In this model, the strategic planning cycle starts with the question of where organization is, continues with the determination of where to go and how to go to the desired future, and finally ends with how success will be measured. In this process, stakeholder and SWOT (strengths, weaknesses, opportunities, threats) analyses are used for analyzing the current situation. The point to be achieved is described with vision, mission, basic principles, goals, and objectives. Strategies and detailed projects are shown on how to achieve the targets. With the whole process, the organization states its strategic plan and long-term intentions.

Ref [39], in their research on the strategic plans of Turkish universities, stated that the strategy is the idea of success created by the organization in order to make a difference between today and the future. Nevertheless, the findings of the researchers show that, except 1 of the 15 universities they studied, all of them have adopted the model of POSP in preparing a strategic plan. Thus, the strategic plans of Turkish universities offer a comparable framework to a large extent, based on the same model. Therefore, the strategic plans of universities are suitable tools for examining the intentions and aims of them. In this research, the strategic plans of universities were subjected to content analysis and the answers of the research questions were sought.

\subsection{Sustainability in the Universities}

Sustainability of the universities not only covers environmental issues, but also sustainable developments in environmental, social, and economic matters [40], and transition to a more sustainable future through research, teaching and learning, industry collaborations, and community bounds [41,42]. It also includes development of graduates to prepare them for more sustainable futures $[42,43]$ and changing universities in accordance with local and national stakeholders' expectations [40]. Many previous studies explored the sustainable development of higher education institutions and they state that sustainable development of the universities can be fostered with the help of the redesign of curricula [44,45], regional and global cooperation [46], or organizational change [40].

In recent years, higher education institutions have faced with many challenges like budget reductions, changing expectations of stakeholders [47], and a continuous and growing demand for higher education [21]. Due to those pressures, universities are now challenging for sustainability and trying to find out new ways to face those expectations for supporting themselves and sustainable development of societies, populations, and stakeholders in which they are embedded [47,48]. According to UNESCO, for a sustainable development, the institution has to be transformed as a whole [47], thus 
transformation of higher education institutions to entrepreneurial universities may be a good response for their sustainable development [49].

\section{Method}

\subsection{Objective and the Research Questions}

The objective of the research was evaluating the Turkish state universities, as to whether they are entrepreneurial universities, and to figure out their intentions to transform into an entrepreneurial university. Within this objective, the research had two research questions, as follows:

RQ1: "Are the Turkish public universities entrepreneurial universities?"

RQ2: "What is the strategic intentions of Turkish public universities on the transformation to entrepreneurial universities and is such a transformation necessary?"

\subsection{Sample}

To address the research questions, it was decided that the strategic plans that indicate the intentions and aims of the institutions would be used as data sources. In this context, the strategic plans of 68 state universities, approved by the POSP and published on the internet at www.sp.gov.tr, were reached in full text during June 2019. All strategic plans cover 3 years and were valid by covering 2019 and 2020.

\subsection{Research Technique}

This research was a qualitative study. In the research, content analysis technique was used. Content analysis is basically a qualitative method and can be defined as "a family of research techniques for making systematic, credible, or valid and replicable inferences from texts and other forms of communication [50]. In this context, content analysis can be defined as a systematic technique, where certain rules are coded and summarized in smaller categories, and some words of a text, key phrases, or words are counted, and frequencies analyzed [51]. Content analysis techniques are not general and ready-made patterns; there are a number of basic rules. Some different analysis techniques like frequency analysis, categorical analysis, evaluative analysis, or relationship analysis can be used in content analysis [52]. In the research, firstly frequency and categorical analysis were performed, and then relationship analysis was used to test the intention-action harmony.

Content analysis is basically a process consisting of some initial steps like setting goals, sampling, determining categories, and evaluating/interpreting [53]. In this research, the objective was first decided, and then university strategic plans were selected as data resources. In the third stage of the study, the units to be divided, the expressions, and categories to be searched within the sample were determined. While doing this, firstly the entrepreneurship and entrepreneurial university literature were examined in detail, and the words to be searched within the strategic plans of the universities were decided.

In the literature, it is emphasized that innovation and creativity are the underlying factors of entrepreneurship in almost all studies. What makes a person an entrepreneur is the ability to create a new organization, a new perspective in the market, new corporate values, new production processes, new products, or new ways of doing business. All entrepreneurial activities are actually wrapped around creating new ideas. Therefore, in determining the intention of universities to transform into an entrepreneurial university, the words "innovation/innovativeness", "creative/creativity", and "entrepreneurship /entrepreneur" were identified as key expressions. However, although these statements define entrepreneurial actions, they are not sufficient to define the entrepreneurial university. Thus, "patent", "university-industry cooperation", and "technopark/technocity", evaluated as pointing to the entrepreneurial university, were searched within the strategic plans of the universities, based on the definition of the entrepreneurial university and the emphasis of various authors. The findings of the fourth stage are presented in the following sections. 


\section{Findings}

The research findings are presented under three different headings. Firstly, frequency distributions were found by counting the keywords in each strategic plan and these expressions were divided into basic categories and categorical frequencies were calculated. Secondly, strategic plans were examined in detail and the intentions related to keywords in strategy and strategic objectives were investigated. Lastly, the intention-action harmony was searched by relationship analyses.

\subsection{Frequencies of the Keywords}

When analyzing the frequency distributions of the keywords, it was determined in which part of the strategic plan the keyword is mentioned. In the strategic plans, the vision, mission, and values that reveal "where the university wants to reach"; the SWOT analysis findings indicating "what is the current position" and the strategy/strategic objectives that show "how to reach the desired location" were examined under separate headings, and different categories were formed. In this context, " 1 " was placed where the keyword was mentioned and if there was no phrase, the relevant field was left blank. University names were kept confidential and a code number was used for each university.

The frequency distributions related to the keywords of "innovation, creativity and entrepreneurship" are presented in Table A1. Accordingly, the first group of keywords was not available anywhere in the strategic plan of only one university strategic plan. In the university strategic plans where the keywords were used, these expressions were mostly repeated within the values indicating the place to be reached (62 plans (91.1\%)). Accordingly, creativity was used $22(32.35 \%)$ times in Vision/Mission/Values parts of the strategic plans at the highest rate while innovation was used 54 $(79.41 \%)$ times in the same parts, and entrepreneurship was used 37 (54.41\%) times in Strategy/Strategic Objectives parts.

In Vision/Mission/Values parts of the strategic plans, 22 (32.35\%) of them included "creativity", $54(79.41 \%)$ of them included "innovation", and 33 (48.53\%) of them consisted of "entrepreneurship" keywords. The majority of those keywords were written among values of the universities.

In the SWOT (strengths, weaknesses, opportunities, threats) sections of the plans, very few universities mentioned the keywords. Only $15(22 \%)$ of the plans included keywords in strengths, 8 $(11.7 \%)$ of them in weaknesses, $5(7.3 \%)$ in opportunities, and $1(1.4 \%)$ in threats. These figures show that the strategic plans of the universities have some gaps in analyzing the current positions of the universities for going through an entrepreneurial university.

When the strategy/strategic objectives parts that show how to reach the desired locations were examined, it was found that $5(7.35 \%)$ plans included the keyword of "creativity", 36 (52.94\%) of them had "innovation", and 37 (54.41\%) of them contained "entrepreneurship".

The frequencies of the second group of keywords "patent, university-industry cooperation, technopark/technocity" are given in Table A2. When the percentages regarding these statements were evaluated in general, it was seen that Turkish universities are still at the beginning, behind the transformation to an entrepreneurial university. Although the percentages under the heading "strategy/strategic objectives" were above 50\%, the majority of the intentions described here, as will be discussed in the following chapters, were intended to achieve a number of processes, opportunities, and capabilities that do not yet exist, rather than the use of existing capabilities.

The second group of keywords were not available anywhere in the strategic plans of two $(2.94 \%)$ universities' strategic plans. The second group of keywords was used more in the "SWOT analysis" and "strategy/strategic objectives" sections rather than the "vision, mission, values" sections. Accordingly, while many of the university strategic plans had "patent" and "technopark/technocity" keywords in the "vision, mission or values" sections, only three (4.41\%) strategic plans emphasized university-industry cooperation in these parts of the plans.

When the SWOT analysis parts of the plans were analyzed, it was seen that the second group of keywords were expressed in the "weaknesses and threats" sections that emphasize the negative characteristics, while the first group of the keywords were mostly included in "strengths and 
opportunities" sections showing the positive characteristics. According to this, the "patent" expression was stated as a strength six (8.82\%) times and opportunity once $(1.47 \%)$; seven $(10.29 \%)$ were in the weakness part of the plans. On the other hand, university-industry cooperation was mentioned as "strengths" in 10 (14.71\%) plans, "opportunities" in 9 (13.24\%) plans, "weaknesses" in 16 (23.53\%), and "threats" in $5(7.35 \%)$ plans. The term technocity/technopark was expressed as a strong aspect in 18 $(26.47 \%)$ strategic plans and as an opportunity in $7(10.29 \%)$ plans, while as a weakness in $9(13.24)$ plans and as threats in $2(2.94 \%)$ plans.

When the strategy/strategic objectives sections of the university strategic plans were examined, $41(60.29 \%)$ of the university strategic plans included the term of "patent", $42(61.76 \%)$ of them included "university-industry cooperation", and 32 (47.06\%) of the plans had "technocity/technopark" statements. However, an important issue to be mentioned here is that although the second group of keywords were included in a significant number of the strategic plans, the majority of them were intentions related to the projects and programs planned for the future rather than intentions for surviving established systems. This is a feature that should be considered in the assessment of the existing capabilities.

\subsection{Intentions in Strategies/Strategic Objectives}

As mentioned in the previous chapters, strategic objectives of a strategic plan indicate the actual intentions and actions of the organization. Therefore, at this stage of the analysis, the strategies/strategic objectives in the strategic plans of the universities were examined in detail and the tacit intentions were examined.

Strategic plan of the University 2 had a strategic objective as "improving pioneering and innovative technological infrastructure", University 7 had "being leader in innovation and patents and increasing the number of scientific publications", University 49 had "... at least $20 \%$ of the courses would be innovation and entrepreneurship based", University 60 had "opening creativity and innovation related courses", and University 69 had a strategic objective of "developing new education and training policies in order to have creative, innovative and entrepreneurial graduates".

The keyword of "entrepreneurship" was widely used in the strategic objective parts of the strategic plans. In the strategic plan, University 8 stated "supporting programs to enhance the entrepreneurship ecosystem", University 18 pointed out "to have entrepreneurship courses in undergraduate programs", "to develop and expand the entrepreneurship culture within the university", University 33 said "to develop entrepreneurial features of academic and administrative staff", and University 38 offered "to encourage academics for establishing spin-offs". Strategic plans offer different actions for supporting entrepreneurial orientation such as "offering courses on entrepreneurship", "fostering entrepreneurial spirit of students by entrepreneurship contests", "increasing internship activities", "supporting academicians' spin-offs", and "making academic entrepreneurship a criterion for academic promotion". Nine of the university strategic plans included "entrepreneurial university" terms; three of them mentioned it as a strategic objective while the other six plans used the term in vision/mission/values or environmental analysis parts.

When the second group of keywords were analyzed in strategic objectives, University 4 used "encouraging patents and taking at least three patents until the end of planning term", University 7 stated "being pioneer in innovation and patents", University 24 wrote "commercializing patents and making connections with private companies for transforming projects to products", and University 61 said "having six new patents until the end of 2021". The majority of the university strategic plans $(60 \%)$ had at least one strategic objective about patenting issues.

University 22 stated "to increase the number of academician founded firms and students who uses incubation center in Technopark until the end of year 2021", University 41 said "initiate some activities to encourage new company foundations in the Technopark", and University 48 mentioned "to empower and functionalize the Technocity". However, some strategic plans discussed the deficiencies of the Technoparks. University 22 wrote "unwillingness of academicians for establishing companies in 
the Technopark" and some newly founded universities (University 56, University 2, University 16, etc.) had strategic objectives of "founding/finishing the establishment of Technopark". Thus, especially for the newly founded universities, Technopark/Technocity term was mainly used as an intention for the future but not developing an existing capability.

For university-industry cooperation (UIC), University 3, University 19, University 20, University 34, University 40, University 44, and University 50 stated "to develop university-industry cooperation" as an important strategic objective. University 34 stated "using student summer internships for university-industry cooperation", and University 33 and 57 said "strengthening university-industry cooperation in order to make internship trainings more efficient and increase internship rates". The majority of the strategic plans mentioned significant gaps for establishing a well-running UIC.

\subsection{Harmony of Intention-Action}

Finally, a relational analysis was conducted to examine what the universities wanted to do and how they would do it, and the harmony between the intention-action of the university strategic plans for entrepreneurial university transformation was questioned.

The primary reason for investigating such a harmony is the findings of frequency distributions. As stated above, $91.1 \%$ of the university strategic plans included the first group of keywords in the value/mission/vision sections, which indicated the intentions, while only $66.1 \%$ of the universities listed the first group of keywords in strategic objectives, which state the actions. These figures show that many intentions will not result in action because no strategy has been developed for this intention.

When the frequency of first group of keywords was examined, it was seen that $22(32 \%)$ strategic plans included keywords in vision/mission/values or SWOT analyses parts, which state intentions, but they did not use those words for any organizational strategy. However, 18 strategic plans of the universities included keywords in all parts of the plans stating a proper intention-action harmony. For the second group of keywords, there was a reverse finding. Only $4.4 \%$ of the university strategic plans included second group of keywords in vision/mission/values sections, and $42.6 \%$ of them used those keywords as "weakness", however $85.3 \%$ of the plans stated some organizational strategies about keywords. Only nine of the plans included the words "entrepreneurial university" as a strategic goal. Most of the strategic plans stated the importance of keywords especially in values or missions, but those plans had significant gaps in defining organizational strategies in order to achieve those values/intentions, pointing out a lack of intention-action harmony.

\section{Discussion and Conclusions}

Within this research, the strategic plans of the Turkish universities were examined and the existence of intention towards transformation to an entrepreneurial university was questioned. When the findings were evaluated in general, it was understood that Turkish universities need to go a long way in terms of transformation into an entrepreneurial university.

The first question sought in the scope of the research was "are Turkish universities entrepreneurial universities?" According to the results of the content analysis conducted within the strategic plans of the universities in the framework of the determined keywords, the answer that can be given to this question is "no". It was seen that the first group of keywords (creativity, innovation, entrepreneurship) and the second group of keywords (patent, university-industry cooperation, technopark/technocity) were not included in four of the strategic plans. Although this figure seems significantly low, the detailed analyses showed that the first group of keywords was mainly used in values sections while the second group of keywords was often evaluated for weaknesses or threats. In addition, the strategic objectives of university-industry cooperation and technocity/technopark were mostly used as a desire to eliminate the existing deficiencies rather than the use of capabilities in hand, supporting the idea that the majority of Turkish universities are not yet entrepreneurial universities.

Many authors define the entrepreneurial university, in addition to education and research, through the university-industry cooperation, the transformation of the research into a commercial 
value, creating economic value for the city in which the university is located, and the contribution of entrepreneurial enterprises to the economy of both graduates and faculty members by establishing new enterprises through entrepreneurial actions. The authors of [25], who gives a good example of this, states that Lenovo, a university-founded company with the support of Beijing University, has had great success in the computer sector and has been transformed into a big company that financially supports the university over time. In this sense, it cannot be said that such entrepreneurial actions exist in the Turkish university system yet.

The second question to be answered was "do Turkish universities have any intention of becoming an entrepreneurial university?" Although the results of the analysis on the keywords revealed that Turkish universities are behind in the transformation to entrepreneurial universities, the majority of the universities have serious intentions and efforts in this direction. When the strategic plans of the universities were examined, it was understood that the majority of them included the keywords in the strategic objective parts of the plans. More than half of the Turkish universities had identified strategic objectives for obtaining patents, increasing university-industry cooperation, establishing or developing technocity/technoparks, and supporting innovative and entrepreneurial activities. These findings, although clearly expressed in the strategic plan of only nine universities, show that there is a clear intention and effort to transform into an entrepreneurial university.

Is such a transformation necessary and, if necessary, how can it be carried out? These questions can be answered in many ways, either positive or negative. As a matter of fact, the author [54] states in his research examining the views of faculty members about entrepreneurial university and university-industry cooperation that there are various supportive and opposing views on this issue; however, as one faculty member says, "the love of running after the knowledge that used to be of no use in the past found a place in the university, today this spirit is gradually began to be abandoned". Similarly, the author [33] states that active and strong ties between universities and the business world have not been established yet. In this context, he argues that it is highly debatable how the country can achieve the goals set for the next decades without a strong link between the university and industry (i.e., to some extent transforming into an entrepreneurial university).

Many obstacles such as various legislative problems, the rigid structure of established corporate culture, social cultural judgments, or ethical concerns can be listed for Turkish universities on the way to entrepreneurial transformation. However, it is important to remember that all these obstacles were once a problem for other societies and universities, but were somehow solved. It is possible to find such successful entrepreneurial university practices in many different countries. The success stories in these universities have been subject to different researches and important lessons have been put forward for other universities trying to change in this direction. For example, the author of [13] discussed the Swedish university system and the transformation of Chalmers University, the author in [4] argued the change of the University of Waterloo, the author in [22] shared the experiences of Massachusetts Institute of Technology, and the author in [55] examined the transformation of the University of Twente to the entrepreneurial university and their contributions to the local economy. In addition to this, the authors in [29] suggested that in order to become an entrepreneurial university, in addition to education and training, graduates are equipped with entrepreneurial spirit, conducting research with various stakeholders in a way that will be transformed into a commercial product; in order to become an entrepreneurial university, the students are constantly supported to establish their own businesses and the structure is transformed to support innovative, creative, and entrepreneurial actions within the university.

Considering the pressure of change created by economic, political, social, and technological changes on higher education institutions and the vision and targets of the country for the future, it seems an important requirement for Turkish universities to be entrepreneurial universities. Keeping in mind that the goals related to the future cannot be achieved without generating information and creating value, it can be said that such a transformation is also a social responsibility. As a result, the existence of Turkish universities, which are in effective communication with all stakeholders, 
support the economic and social development of the region, transform their graduates into productive individuals, and are the leading actors of technological development in the country, will be a common benefit for the whole society.

\subsection{Managerial Implications}

One potential weakness of the universities, depending on their strategic plans, is the lack of effective university-industry collaboration. Managers and policy makers of higher education institutions should find some creative ways to encourage and develop the UIC. Some legal issues might be in consideration, specifically to stimulate the academicians for founding strong ties with the industry and establishing start-ups within the technocities/technoparks. Also, the collaboration with technocities/technoparks is mainly on basic research relations or internship programs for the students. However, for transforming to entrepreneurial universities, Turkish universities should find new ways to develop the collaborations with those technology centers.

As is the case in a few universities, academic qualifications and performance evaluations might be associated with the academicians' entrepreneurial activities. Some success stories can be shared within the universities and academics can be encouraged towards more entrepreneurship. In this sense, creating a shared value system [56] within the institution may facilitate a transition to an entrepreneurial structure.

\subsection{Limitations and Recommendations for Future Studies}

In addition to the important findings, the study has some limitations. First, the data source was a limitation. In this study, instead of obtaining direct opinions of university administrators by means of questionnaires, interviews, or observations, the strategic plans of the universities, which were evaluated as expressing their strategic intentions and objectives as an institution, were examined. In this context, the number of strategic plans included in the research constitutes a limitation. The sample of the research was limited to the strategic plans published at www.sp.gov.tr.

The issue that needs to be expressed in relation to this is that all of the university strategic plans examined in the scope of this research were public universities. There are many foundation universities in Turkey and some of them have entrepreneurship research centers and technocity/technopark and some of them have very serious talent and potential towards entrepreneurial university. However, this research does not include foundation universities. Therefore, if one of the primary data collection methods is selected as a method in future researches, it can provide data collection from foundation universities as well as conducting studies comparing public universities and foundation universities.

A second limitation was the selected keywords. Within the scope of the research, the words "innovation, creativity, entrepreneurship, patent, university-industry cooperation and technocity/technopark" were chosen as the keywords after searching the existing literature. Similar research can be done by using different keywords in addition to these words in future studies.

Future studies may focus on the possible advantages and disadvantages of central strategic planning in higher education. As is the case in Turkish universities, most of the university strategic plans follow the method of POSP, and two possible advantages of this approach can be resource optimization and strategic vision guidance; however, a potential disadvantage may be the institutional isomorphism [57] of the universities in the future. These pros and cons need further research.

Finally, strategic plans are documents that show long-term intentions. For this reason, it is considered that strategic plans should be monitored in future studies. Since strategic planning is a new concept in Turkish higher institutions, there is not enough data for such a longitudinal analysis yet. However, it is thought that such a research can be conducted by comparing the following term strategic plans with current ones.

Author Contributions: Conceptualization, H.S. and S.Y.G.; methodology, H.S.; software, H.S. and D.K.; validation, H.S., D.K., and S.S.; formal analysis, H.S., D.K., S.Y.G., and R.A.C.; investigation, D.K.; resources, H.S.; data curation, H.S.; writing—original draft preparation, H.S., D.K., and S.Y.G.; writing—review and editing, H.S., 
R.A.C., and S.Y.G.; visualization, S.S.; supervision, R.A.C. and S.Y.G.; project administration, R.A.C., S.S., and D.K. All authors have read and agreed to the published version of the manuscript.

Funding: This research received no external funding.

Acknowledgments: We confirmed that this manuscript has not been published elsewhere and is not under consideration by another journal. In addition, we also confirmed that this research did not receive any specific grant from funding agencies in the public, commercial, or not-for-profit sectors. We have no conflicts of interest to disclose. Ethical approval and Informed consent do not applicable for this study.

Conflicts of Interest: The authors declare no conflict of interest.

\section{Appendix A}

Table A1. Frequency of creativity, innovation, and entrepreneurship.

\begin{tabular}{|c|c|c|c|c|c|c|c|c|c|c|c|c|c|c|c|c|c|c|c|}
\hline \multirow[t]{2}{*}{ N. } & \multirow[t]{2}{*}{ University } & \multicolumn{3}{|c|}{$\begin{array}{c}\text { Vis./Miss./ } \\
\text { Values }\end{array}$} & \multicolumn{3}{|c|}{ Strengths } & \multicolumn{3}{|c|}{ Weakness } & \multicolumn{3}{|c|}{ Opport. } & \multicolumn{3}{|c|}{ Threats } & \multicolumn{3}{|c|}{ Org. Str. } \\
\hline & & $\mathrm{C}$ & $\mathbf{I}$ & $\mathbf{E}$ & $\mathrm{C}$ & $\mathbf{I}$ & $\mathrm{E}$ & $\mathrm{C}$ & I & $\mathbf{E}$ & $\mathrm{C}$ & $\mathbf{I}$ & $\mathbf{E}$ & $\mathrm{C}$ & I & $\mathrm{E}$ & $\mathrm{C}$ & I & $\mathrm{E}$ \\
\hline 1 & University 1 & 1 & & & & & & & & & & & & & & & & 1 & \\
\hline 2 & University 2 & 1 & 1 & & & & & & & & & 1 & & & & & & 1 & 1 \\
\hline 3 & University 3 & 1 & & & & & & & & & & & & & & & & 1 & 1 \\
\hline 4 & University 4 & 1 & 1 & & & & & & & & & & & & & & & & 1 \\
\hline 5 & University 5 & 1 & 1 & & & & & & & & & & & & & & & 1 & 1 \\
\hline 6 & University 6 & & & & & & & & & & & & & & & & & 1 & 1 \\
\hline 7 & University 7 & & 1 & & & & & & & & & & & & & & & & \\
\hline 8 & University 8 & 1 & 1 & 1 & & & & & & & & & & & & & 1 & 1 & 1 \\
\hline 9 & University 9 & & 1 & 1 & & & & & & 1 & & & & & & & & 1 & 1 \\
\hline 10 & University 10 & & & & & & & & & & & & & & & & & & \\
\hline 11 & University 11 & 1 & & & & & & & & & & & & & & & & & \\
\hline 12 & University 12 & & & & & & & & & 1 & & & & & & & & 1 & 1 \\
\hline 13 & University 13 & & 1 & 1 & & & & & & & & & & & & & & & \\
\hline 14 & University 14 & 1 & 1 & & & 1 & 1 & & 1 & & & & & & & & & & \\
\hline 15 & University 15 & & 1 & 1 & & & & & & & & & & & & & & & \\
\hline 16 & University 16 & & 1 & 1 & & 1 & & & & & & & & & & & & 1 & 1 \\
\hline 17 & University 17 & & 1 & 1 & & & & & & & & & & & & & & 1 & 1 \\
\hline 18 & University 18 & 1 & 1 & & & & & & & & & & & & & & & 1 & 1 \\
\hline 19 & University 19 & 1 & 1 & 1 & & & & & & & & & & & & & & 1 & 1 \\
\hline 20 & University 20 & 1 & 1 & & & 1 & & & & & & & & & & & & & \\
\hline 21 & University 21 & 1 & 1 & 1 & & 1 & & & & & & 1 & 1 & & & & & 1 & 1 \\
\hline 22 & University 22 & & 1 & 1 & & & & & & & & & & & & & & & \\
\hline 23 & University 23 & & 1 & 1 & & & 1 & & & & & & & & & & & 1 & 1 \\
\hline 24 & University 24 & & & 1 & & & & & & & & & & & & & 1 & 1 & 1 \\
\hline 25 & University 25 & & 1 & & & & & & & & & & & & & & & & \\
\hline 26 & University 26 & & 1 & & & & & & & & & & & & & & & & \\
\hline 27 & University 27 & & & & & & & & & & & & & & & & & 1 & 1 \\
\hline 28 & University 28 & & 1 & 1 & & & & & & & & & & & & & & & \\
\hline 29 & University 29 & & 1 & & & & & & & & & & & & & & & & 1 \\
\hline
\end{tabular}


Table A1. Cont.

\begin{tabular}{|c|c|c|c|c|c|c|c|c|c|c|c|c|c|c|c|c|c|c|c|}
\hline \multirow[t]{2}{*}{ N. } & \multirow[t]{2}{*}{ University } & \multicolumn{3}{|c|}{$\begin{array}{c}\text { Vis./Miss./ } \\
\text { Values }\end{array}$} & \multicolumn{3}{|c|}{ Strengths } & \multicolumn{3}{|c|}{ Weakness } & \multicolumn{3}{|c|}{ Opport. } & \multicolumn{3}{|c|}{ Threats } & \multicolumn{3}{|c|}{ Org. Str. } \\
\hline & & $\mathrm{C}$ & I & $\mathrm{E}$ & $\mathrm{C}$ & I & $\mathrm{E}$ & $\mathrm{C}$ & I & $\mathbf{E}$ & $\mathrm{C}$ & I & E & $\mathrm{C}$ & I & $\mathrm{E}$ & $\mathrm{C}$ & I & $\mathrm{E}$ \\
\hline 30 & University 30 & & & 1 & & & & & & & & & & & & & & & 1 \\
\hline 31 & University 31 & & 1 & & & & & & & & & & & & & & & & \\
\hline 32 & University 32 & 1 & 1 & 1 & & & & & & & & & & & & & & & 1 \\
\hline 33 & University 33 & & 1 & 1 & & & & & & 1 & & & 1 & & & & & & 1 \\
\hline 34 & University 34 & & & 1 & & & & & & & & & & & & & & & \\
\hline 35 & University 35 & 1 & & & 1 & & & & & & & & & & & & & & \\
\hline 36 & University 36 & & 1 & 1 & & & & & & & & & & & & & & 1 & 1 \\
\hline 37 & University 37 & 1 & 1 & & & & & & & & & & & & & & 1 & 1 & 1 \\
\hline 38 & University 38 & & 1 & & & 1 & & & & & & 1 & & & & & & 1 & 1 \\
\hline 39 & University 39 & 1 & 1 & 1 & & & & & & & & & & 1 & & & & 1 & \\
\hline 40 & University 40 & 1 & 1 & & & & & & & & & & & & & & & 1 & 1 \\
\hline 41 & University 41 & & 1 & 1 & & 1 & & & & & & & & & & & & 1 & \\
\hline 42 & University 42 & & 1 & 1 & & & & & & & & & & & & & & & 1 \\
\hline 43 & University 43 & & 1 & & & & & & & & & & & & & & & & \\
\hline 44 & University 44 & & 1 & 1 & & & & & & & & & 1 & & & & & 1 & 1 \\
\hline 45 & University 45 & & 1 & 1 & & 1 & 1 & & & & & & & & & & 1 & 1 & 1 \\
\hline 46 & University 46 & & 1 & 1 & & & & & & & & & & & & & & & \\
\hline 47 & University 47 & & & & & & & & & & & & & & & & & & 1 \\
\hline 48 & University 48 & 1 & 1 & 1 & & & & & & 1 & & & & & & & & 1 & 1 \\
\hline 49 & University 49 & & 1 & 1 & & & & & & & & & & & & & & & \\
\hline 50 & University 50 & & 1 & 1 & & 1 & & & & & & & & & & & & 1 & \\
\hline 51 & University 51 & & 1 & & & 1 & & & & 1 & & & & & & & & 1 & \\
\hline 52 & University 52 & & 1 & & & & & & & & & & & & & & & & \\
\hline 53 & University 53 & 1 & 1 & 1 & & & & & & & & & & & & & & & \\
\hline 54 & University 54 & & 1 & & & & & & & & & & & & & & & 1 & 1 \\
\hline 55 & University 55 & & & 1 & & & & & & & & & & & & & & & 1 \\
\hline 56 & University 56 & & & & & & & & & & & & & & & & & 1 & 1 \\
\hline 57 & University 57 & 1 & 1 & 1 & & & & & & & & & & & & & & 1 & 1 \\
\hline 58 & University 58 & 1 & 1 & & & & & & & 1 & & & & & & & & 1 & \\
\hline 59 & University 59 & & 1 & & & 1 & & & & & & & & & & & 1 & 1 & 1 \\
\hline 60 & University 60 & 1 & 1 & & & & & & & & & & & & & & & & 1 \\
\hline 61 & University 61 & & 1 & 1 & & & & & & & & & & & & & & & \\
\hline 62 & University 62 & & 1 & & & & & & & & & & & & & & & & \\
\hline 63 & University 63 & & 1 & & & & & & & & & & & & & & & & \\
\hline 64 & University 64 & & 1 & 1 & & 1 & 1 & & 1 & & & & & & & & & 1 & 1 \\
\hline 65 & University 65 & & 1 & & & 1 & & & & & & & & & & & & & \\
\hline 66 & University 66 & & 1 & 1 & & & & & & & & & & & & & & 1 & 1 \\
\hline
\end{tabular}


Table A1. Cont.

\begin{tabular}{|c|c|c|c|c|c|c|c|c|c|c|c|c|c|c|c|c|c|c|c|}
\hline \multirow[t]{2}{*}{ N. } & \multirow[t]{2}{*}{ University } & \multicolumn{3}{|c|}{$\begin{array}{c}\text { Vis./Miss./ } \\
\text { Values }\end{array}$} & \multicolumn{3}{|c|}{ Strengths } & \multicolumn{3}{|c|}{ Weakness } & \multicolumn{3}{|c|}{ Opport. } & \multicolumn{3}{|c|}{ Threats } & \multicolumn{3}{|c|}{ Org. Str. } \\
\hline & & $\mathrm{C}$ & I & $E$ & $\mathrm{C}$ & I & $\mathrm{E}$ & $\mathrm{C}$ & I & $\mathrm{E}$ & $\mathrm{C}$ & I & $\mathrm{E}$ & $\mathrm{C}$ & I & $\mathrm{E}$ & $\mathrm{C}$ & I & $E$ \\
\hline 67 & University 67 & & 1 & & & & & & & & & & & & & & & 1 & \\
\hline \multirow[t]{2}{*}{68} & University 68 & & 1 & 1 & & 1 & & & & & & & & & & & & 1 & \\
\hline & Total & 22 & 54 & 33 & 1 & 13 & 4 & 0 & 2 & 6 & 0 & 3 & 3 & 1 & 0 & 0 & 5 & 36 & 37 \\
\hline & Percentage & 32.3 & 79.4 & 448.5 & 1.4 & 19.1 & 15.8 & 0.0 & 2.9 & 8.8 & 0.0 & 4.4 & 4.4 & 1.4 & 0.0 & 0.0 & 7.3 & 52. & 954.4 \\
\hline \multicolumn{2}{|c|}{$\begin{array}{c}\text { Number/percentage } \\
\text { of "full" } \\
\text { universities }\end{array}$} & \multicolumn{3}{|c|}{$62(91.1 \%)$} & \multicolumn{3}{|c|}{$15(22 \%)$} & \multicolumn{3}{|c|}{$8(11.7 \%)$} & \multicolumn{3}{|c|}{$5(7.3 \%)$} & \multicolumn{3}{|c|}{$1(1.4 \%)$} & \multicolumn{3}{|c|}{$45(66.1 \%)$} \\
\hline \multicolumn{2}{|c|}{$\begin{array}{c}\text { Number/percentage } \\
\text { of "empty" } \\
\text { universities }\end{array}$} & \multicolumn{3}{|c|}{$6(8.9 \%)$} & \multicolumn{3}{|c|}{$53(78 \%)$} & \multicolumn{3}{|c|}{$60(88.3 \%)$} & \multicolumn{3}{|c|}{$63(92.7 \%)$} & \multicolumn{3}{|c|}{$67(98.6 \%)$} & \multicolumn{3}{|c|}{23 (33.9\%) } \\
\hline
\end{tabular}

Table A2. Frequency of patent, university-industry cooperation, and technopark/technocity.

\begin{tabular}{|c|c|c|c|c|c|c|c|c|c|c|c|c|c|c|c|c|c|c|c|}
\hline \multirow[t]{2}{*}{ N. } & \multirow[t]{2}{*}{ University } & \multicolumn{3}{|c|}{$\begin{array}{c}\text { Vis./Miss./ } \\
\text { Values }\end{array}$} & \multicolumn{3}{|c|}{ Strengths } & \multicolumn{3}{|c|}{ Weakness } & \multicolumn{3}{|c|}{ Opport. } & \multicolumn{3}{|c|}{ Threats } & \multicolumn{3}{|c|}{ Org. Str. } \\
\hline & & $\mathbf{P}$ & $\mathbf{U}$ & $\mathbf{T}$ & $\mathbf{P}$ & $\mathbf{U}$ & $\mathrm{T}$ & $\mathbf{P}$ & $\mathbf{U}$ & $\mathbf{T}$ & $\mathbf{P}$ & $\mathbf{U}$ & $\mathbf{T}$ & $\mathbf{P}$ & $\mathbf{U}$ & $\mathbf{T}$ & $\mathbf{P}$ & $\mathbf{U}$ & $T$ \\
\hline 1 & University 1 & & & & & & & 1 & & & 1 & & 1 & & & & 1 & 1 & 1 \\
\hline 2 & University 2 & & & & & & & & 1 & & & 1 & & & & 1 & 1 & 1 & 1 \\
\hline 3 & University 3 & & & & & & & & & & & 1 & & & & & 1 & 1 & 1 \\
\hline 4 & University 4 & & & & & & & & & & & 1 & & & & & 1 & 1 & \\
\hline 5 & University 5 & & & & & & & & & & & & & & & & 1 & & 1 \\
\hline 6 & University 6 & & & & & & 1 & & & & & & & & & & 1 & 1 & 1 \\
\hline 7 & University 7 & & & & 1 & & & & & & & 1 & 1 & & & & & & \\
\hline 8 & University 8 & & & & & 1 & 1 & & & & & & & & & & 1 & 1 & 1 \\
\hline 9 & University 9 & & & & 1 & & & & 1 & & & & & & & & 1 & 1 & \\
\hline 10 & University 10 & & & & & & & & 1 & & & & & & & & & 1 & 1 \\
\hline 11 & University 11 & & & & & & & & & & & & 1 & & & & 1 & & \\
\hline 12 & University 12 & & & & & & & & & & & & & & & & 1 & 1 & 1 \\
\hline 13 & University 13 & & & & & & & & & & & & & & & & 1 & 1 & \\
\hline 14 & University 14 & & & & & 1 & 1 & & & & & & & & & & 1 & 1 & \\
\hline 15 & University 15 & & & & & & & & 1 & & & & 1 & & & & 1 & 1 & 1 \\
\hline 16 & University 16 & & & & & & & & 1 & & & & & & & & & 1 & 1 \\
\hline 17 & University 17 & & & & & 1 & 1 & & & & & & & & & & & & \\
\hline 18 & University 18 & & & & & & & & & & & & & & & & 1 & & 1 \\
\hline 19 & University 19 & & & & 1 & & 1 & & & & & & & & & & 1 & 1 & \\
\hline 20 & University 20 & & & & & & & & 1 & & & 1 & & & & & & 1 & 1 \\
\hline 21 & University 21 & & & & & & 1 & & 1 & & & & & & & & 1 & & \\
\hline 22 & University 22 & & & & & & & & & & & 1 & & & & & & 1 & 1 \\
\hline 23 & University 23 & & & & 1 & & 1 & & 1 & & & & & & & & 1 & & 1 \\
\hline 24 & University 24 & & & & & & 1 & & & & & & & & & & & 1 & 1 \\
\hline
\end{tabular}


Table A2. Cont.

\begin{tabular}{|c|c|c|c|c|c|c|c|c|c|c|c|c|c|c|c|c|c|c|c|}
\hline \multirow[t]{2}{*}{ N. } & \multirow[t]{2}{*}{ University } & \multicolumn{3}{|c|}{$\begin{array}{c}\text { Vis./Miss./ } \\
\text { Values }\end{array}$} & \multicolumn{3}{|c|}{ Strengths } & \multicolumn{3}{|c|}{ Weakness } & \multicolumn{3}{|c|}{ Opport. } & \multicolumn{3}{|c|}{ Threats } & \multicolumn{3}{|c|}{ Org. Str. } \\
\hline & & $\mathbf{P}$ & $\mathbf{U}$ & $\mathrm{T}$ & $\mathbf{P}$ & $\mathbf{U}$ & $\mathrm{T}$ & $\mathbf{P}$ & $\mathbf{U}$ & $\mathrm{T}$ & $\mathbf{P}$ & $\mathbf{U}$ & $\mathbf{T}$ & $\mathbf{P}$ & $\mathbf{U}$ & $\mathrm{T}$ & $\mathbf{P}$ & $\mathbf{U}$ & $\mathrm{T}$ \\
\hline 25 & University 25 & & & & & & & & & & & & & & & & 1 & & \\
\hline 26 & University 26 & & & & & 1 & 1 & & & & & & & & & & & 1 & \\
\hline 27 & University 27 & & & & & & & 1 & & & & & 1 & & & & 1 & 1 & \\
\hline 28 & University 28 & & & & & & & & & 1 & & & & & & & 1 & & 1 \\
\hline 29 & University 29 & & & & & 1 & & & & & & & & & & & & 1 & \\
\hline 30 & University 30 & & & & & & & 1 & & 1 & & & & & & & 1 & 1 & 1 \\
\hline 31 & University 31 & & & & & & 1 & 1 & & & & & & & & & 1 & & \\
\hline 32 & University 32 & & & & & & & & & & & & 1 & & & & 1 & 1 & 1 \\
\hline 33 & University 33 & & & & & 1 & 1 & & & & & 1 & & & & & 1 & 1 & 1 \\
\hline 34 & University 34 & & & & & & 1 & & & & & & & & 1 & & 1 & & \\
\hline 35 & University 35 & & & & & & 1 & 1 & 1 & & & 1 & & & & & & & \\
\hline 36 & University 36 & & & & & & 1 & & & & & & & & & & & 1 & 1 \\
\hline 37 & University 37 & & & & 1 & & 1 & & 1 & & & & & & & & 1 & 1 & 1 \\
\hline 38 & University 38 & & & & & & & & & 1 & & & & & 1 & & 1 & 1 & \\
\hline 39 & University 39 & & & & & & & & & & & & 1 & & & & 1 & & 1 \\
\hline 40 & University 40 & & & & & & 1 & & 1 & & & & & & & & 1 & 1 & 1 \\
\hline 41 & University 41 & & & & & & & & & & & & & & & & 1 & 1 & \\
\hline 42 & University 42 & & 1 & & & & & & 1 & & & & & & & & & & \\
\hline 43 & University 43 & & & & & & & 1 & & & & & & & & & & 1 & \\
\hline 44 & University 44 & & & & & & 1 & & & 1 & & & & & & & 1 & & 1 \\
\hline 45 & University 45 & & & & & & & & & & & & & & & & 1 & 1 & 1 \\
\hline 46 & University 46 & & & & & & & & & & & & & & & & 1 & 1 & 1 \\
\hline 47 & University 47 & & & & & & & & & 1 & & & & & & & 1 & & 1 \\
\hline 48 & University 48 & & & & & 1 & & 1 & & & & & & & & & & 1 & \\
\hline 49 & University 49 & & & & & & & & 1 & & & & & & & & 1 & 1 & \\
\hline 50 & University 50 & & & & & & & & & & & & & & 1 & & 1 & & \\
\hline 51 & University 51 & & & & & & & & & & & & & & 1 & & & & \\
\hline 52 & University 52 & & & & & & & & & & & & & & & & & 1 & \\
\hline 53 & University 53 & & & & & 1 & & & & & & & & & & & & & 1 \\
\hline 54 & University 54 & & & & & & & & & 1 & & & & & & & 1 & 1 & \\
\hline 55 & University 55 & & & & & & & & & & & & & & & & 1 & & \\
\hline 56 & University 56 & & & & & & & & & & & & & & & & & 1 & \\
\hline 57 & University 57 & & 1 & & & & & & & & & & & & & & 1 & 1 & 1 \\
\hline 58 & University 58 & & & & & & & & 1 & & & & & & & & & & \\
\hline 59 & University 59 & & & & & & & & & & & & & & & & & & \\
\hline 60 & University 60 & & & & & & 1 & & 1 & & & & & & & & & 1 & \\
\hline 61 & University 61 & & & & & & & & & & & 1 & & & & & & 1 & \\
\hline 62 & University 62 & & & & & & & & & & & & & & 1 & & & & \\
\hline 63 & University 63 & & & & 1 & 1 & & & & & & & & & & & & 1 & \\
\hline
\end{tabular}


Table A2. Cont.

\begin{tabular}{|c|c|c|c|c|c|c|c|c|c|c|c|c|c|c|c|c|c|c|c|}
\hline \multirow[t]{2}{*}{ N. } & \multirow[t]{2}{*}{ University } & \multicolumn{3}{|c|}{$\begin{array}{c}\text { Vis./Miss./ } \\
\text { Values }\end{array}$} & \multicolumn{3}{|c|}{ Strengths } & \multicolumn{3}{|c|}{ Weakness } & \multicolumn{3}{|c|}{ Opport. } & \multicolumn{3}{|c|}{ Threats } & \multicolumn{3}{|c|}{ Org. Str. } \\
\hline & & $\mathbf{P}$ & $\mathbf{U}$ & $\mathrm{T}$ & $\mathbf{P}$ & $\mathbf{U}$ & $T$ & $\mathbf{P}$ & $\mathbf{U}$ & $\mathrm{T}$ & $\mathbf{P}$ & $\mathbf{U}$ & $\mathbf{T}$ & $\mathbf{P}$ & $\mathbf{U}$ & $\mathrm{T}$ & $\mathbf{P}$ & $\mathbf{U}$ & $\mathrm{T}$ \\
\hline 64 & University 64 & & & & & 1 & & & & 1 & & & & & & 1 & 1 & 1 & 1 \\
\hline 65 & University 65 & & & & & & & & 1 & 1 & & & & & & & & & \\
\hline 66 & University 66 & & & & & & & & & & & & & & & & 1 & & 1 \\
\hline 67 & University 67 & & 1 & & & & & & & 1 & & & & & & & & 1 & 1 \\
\hline \multirow[t]{3}{*}{68} & University 68 & & & & & & & & & & & & & & & & & & \\
\hline & Total & 0 & 3 & 0 & 6 & 10 & 18 & 7 & 16 & 9 & 1 & 9 & 7 & 0 & 5 & 2 & 41 & 42 & 32 \\
\hline & Percentage & 0.0 & 4.4 & 0.0 & 8.8 & 14.7 & 726.4 & 10.2 & 23.5 & 13.2 & 1.47 & & .210 .2 & 20.0 & 7.3 & 2.9 & 60.2 & 61.7 & 747.0 \\
\hline \multicolumn{2}{|c|}{$\begin{array}{c}\text { Number/percentage } \\
\text { of "full" } \\
\text { universities }\end{array}$} & \multicolumn{3}{|c|}{$3(4.4 \%)$} & \multicolumn{3}{|c|}{$25(36.7 \%)$} & \multicolumn{3}{|c|}{$29(42.6 \%)$} & \multicolumn{3}{|c|}{$15(22 \%)$} & \multicolumn{3}{|c|}{$7(10.3 \%)$} & \multicolumn{3}{|c|}{$58(85.3 \%)$} \\
\hline \multicolumn{2}{|c|}{$\begin{array}{c}\text { Number/percentage } \\
\text { of "empty" } \\
\text { universities }\end{array}$} & \multicolumn{3}{|c|}{$65(95.6 \%)$} & \multicolumn{3}{|c|}{$43(63.3 \%)$} & \multicolumn{3}{|c|}{$39(57.4 \%)$} & \multicolumn{3}{|c|}{$53(88 \%)$} & \multicolumn{3}{|c|}{61 (89.7\%) } & \multicolumn{3}{|c|}{$10(14.7 \%)$} \\
\hline
\end{tabular}

\section{References}

1. David, P. The Knowledge Factory: A Survey of Universities. Economist 1997, 345, 1-22.

2. Sanchez-Barrioluengo, M.; Benneworth, P. Is the entrepreneurial university also regionally engaged? Analysing the influence of university's structural configuration on third mission performance. Technol. Forecast. Soc. Chang. 2019, 141, 206-218. [CrossRef]

3. Kuhlman, S.; Shapir, P. How is innovation influenced by science and technology policy governance? Transatlantic comparisons. In Innovation, Science, and Institutional Change; Hage, J., Meeus, M., Eds.; Oxford University Press: Oxford, UK, 2006; pp. 232-255.

4. Bramwell, A.; Wolfe, D.A. Universities and Regional Economic Development: The Entrepreneurial University of Waterloo. Res. Policy 2008, 37, 1175-1187. [CrossRef]

5. Etzkowitz, H.; Germain-Alamartine, E.; Keel, J.; Kumar, C.; Smith, K.N.; Albats, E. Entrepreneurial university dynamics: Structured ambivalence, relative deprivation and institution-formation in the Stanford innovation system. Technol. Forecast. Soc. Chang. 2019, 141, 159-171. [CrossRef]

6. Etzkowitz, H. The Norms of Entrepreneurial Science: Cognitive Effects of the New University-Industry Linkages. Res. Policy 1998, 27, 823-833. [CrossRef]

7. Etzkowitz, H. Research Groups as 'Quasi Firms': The Invention of the Entrepreneurial University. Res. Policy 2003, 32, 109-121. [CrossRef]

8. Etzkowitz, H.; Leydesdorff, L. The Dynamics of Innovation: From the National Systems and "Mode 2" to a Triple Helix of University-Industry- Government Relations. Res. Policy 2000, 29, 109-123. [CrossRef]

9. Perkmann, M.; Tartari, V.; McKelvey, M.; Autio, E.; Brostrom, A.; D’Este, P.; Krabel, S. Academic engagement and commercialisation: A review of the literature on university-industry relations. Res. Policy 2013, 42, 423-442. [CrossRef]

10. Etzkowitz, H. Entrepreneurial Scientists and Entrepreneurial Universities in American Academic Science. Minerva 1983, 21, 198-233. [CrossRef]

11. Guerrero, M.; Urbano, D. The development of entrepreneurial university. J. Technol. Transf. 2012, 37, 43-74. [CrossRef]

12. Chrisman, J.; Hynes, T.; Fraser, S. Faculty Entrepreneurship and Economic development: The Case of the University of Calgary. J. Bus. Ventur. 1995, 10, 267-281. [CrossRef]

13. Jacob, M.; Lundqvist, M.; Hellsmark, H. Entrepreneurial Transformations in the Swedish University System: The Case of Chalmers University of Technology. Res. Policy 2003, 32, 1555-1569. [CrossRef]

14. Çiftçi, M. Girişimci Üniversite ve Üçüncü Kuşak Üniversiteler. Dumlupınar Üniversitesi Sosyal Bilimler Dergisi 2010, 27, 341-347. 
15. Drucker, P. Innovation and Entrepreneurship: Practice and Principles; Harper \& Row: New York, NY, USA, 1985.

16. Hisrich, R.D.; Peters, M.P. Entrepreneurship: Starting, Developing, and Managing a New Enterprise; BPI/Irwin: Homewood, IL, USA, 1989.

17. Herron, L.; Robinson, R.B. A Structural Model of the Effects of Entrepreneurial Characteristics on Venture Performance. J. Bus. Ventur. 1993, 8, 281-294. [CrossRef]

18. Schumpeter, J.A. The Theory of Economic Development; Harvard University Press: Cambridge, MA, USA, 1934.

19. Kirzner, I.M. Discovery and Capitalist Process; University of Chicago Press: Chicago, IL, USA, 1985.

20. Dalmarco, G.; Hulsink, W.; Blois, G.V. Creating entrepreneurial universities in an emerging economy: Evidence from Brazil. Technol. Forecast. Soc. Chang. 2018, 135, 99-111. [CrossRef]

21. Clark, B.R. The Entrepreneurial University: Demand and Response. Tert. Educ. Manag. 1998, 4, 5-16. [CrossRef]

22. O'Shea, R.P.; Allen, T.J.; Morse, K.P.; O'Gorman, C.; Roche, F. Delineating the Anatomy of an Entrepreenuria University: The Massachusetts Institute of Technology Experience. $R$ D Manag. 2007, 37, 1-16.

23. Mascarenhas, C.; Marques, C.S.; Galvao, A.R.; Santos, G. Entrepreneurial university: towards a better understanding of past trends and future directions. J. Enterprising Communities People Places Glob. Econ. 2017, 11, 316-338. [CrossRef]

24. Wissema, J.G. Üçüncü Kuşak Üniversitelere Doğru; Özyeğin Üniversitesi Yayınları: Istanbul, Turkey, 2009.

25. Etzkowitz, H.; Ranga, M.; Benner, M.; Guaranys, L.; Maculan, A.M.; Kneller, R. Pathways to the Entrepreneurial University: Towards a Global Convergence. Sci. Public Policy 2008, 35, 681-695. [CrossRef]

26. Röpke, J. The Entrepreneurial University, Innovation, Academic Knowledge Creation and Regional Development in a Globalized Economy; Working Paper; Philipps-Universität Marburg: Marburg, Germany, 1998.

27. Pfeiffer, E.W. What MIT Learned from Stanford. Forbes. 1997, 59. Available online: https://www.forbes.com/ asap/1997/0825/059.html (accessed on 10 February 2020).

28. Martinelli, A.; Meyer, M.; Tunzelmann, N.V. Becoming an Entrepreneurial University? A Case Study of Knowledge Exchange Relationships and Faculty Attitudes in a Medium-sized, Research-oriented University. J. Technol. Transf. 2008, 33, 259-283. [CrossRef]

29. Schulte, P. The Entrepreneurial University: A Strategy for Institutional Development. High. Educ. Eur. 2004, 29, 187-191. [CrossRef]

30. Mowery, D.C.; Ziedonis, A.A. Market Failure or Market Magic? Structural Change in the US National Innovation System. Soc. Sci. Ind. Rev. 1998, 22, 101-136.

31. Zaharia, S.E.; Gibert, E. The Entrepreneurial University in the Knowledge Society. High. Educ. Eur. 2005, 30, 31-40. [CrossRef]

32. Council of Higher Education (Yüksek Öğretim Kurulu). Türkiye’nin Yükseköğretim Stratejisi; Yükseköğretim Kurumu: Ankara, Turkey, 2007.

33. Günay, D. Türk Yükseköğretiminin Yeniden Yapılandırılması Bağlamında Sorunlar, Eğilimler, İlkeler ve Öneriler-I. Yükseköğretim ve Bilim Dergisi 2011, 1, 113-121.

34. Caulfield, J.; Schultz, J. Planning for Change, Strategic Planning in Local Government; Longman Group: London, UK, 1989.

35. Mintzberg, H.; Quin, J.B. The Strategy Process: Concepts, Contexts, and Cases; Prentice Hall: Englewood Cliffs, NJ, USA, 1996.

36. Yozgat, U.; Duran, F. Strateji Geliştirme Sürecinde Üst Yönetim Bilgi Sistemleri Kullanımı; 9uncu Ulusal Yönetim ve Organizasyon Kongresi Bildiriler Kitabi: Istanbul, Turkey, 2001; pp. 871-883.

37. Barry, B.W. Strategic Planning Workbook for Public and Nonprofit Organizations; Wilder Foundation: Saint Paul, MN, USA, 1986.

38. Bryson, J.M. Strategic Planning and Action Planning for Public and Nonprofit Organizations; Jossey-Bass: San Francisco, CA, USA, 1988.

39. Barca, M.; Geyik, M. Stratejik Planlama Çalışmaları Kamu İdarelerinde Benzeşmeye Yol Açıyor Mu? 16ncı Ulusal Yönetim ve Organizasyon Kongresi Bildiriler Kitabı: Antalya, Turkey, 2008; pp. 233-242.

40. Vargas, V.R.; Lawthom, R.; Prowse, A.; Randles, S.; Tzoulas, K. Sustainable development stakeholder networks for organisational change in higher education institutions: A case study from the UK. J. Clean. Prod. 2019, 208, 470-478. [CrossRef]

41. Murray, J. Student-led action for sustainability in higher education: A literature review. Int. J. Sustain. High. Educ. 2018, 19, 1095-1110. [CrossRef] 
42. Gramatakos, A.L.; Lavau, S. Informal learning for sustainability in higher education institutions. Int. J. Sustain. High. Educ. 2019, 20, 378-392. [CrossRef]

43. Shephard, K. Higher education for sustainability: seeking affective learning outcomes. Int. J. Sustain. High. Educ. 2008, 9, 87-98. [CrossRef]

44. Du, X.; Su, L.; Liu, J. Developing sustainability curricula using the PBL method in a Chinese context. J. Clean. Prod. 2013, 61, 80-88. [CrossRef]

45. Brent Edwards, D., Jr.; Sustarsic, M.; Chiba, M.; McCormick, M.; Goo, M.; Perriton, S. Achieving and Monitoring Education for Sustainable Development and Global Citizenship: A Systematic Review of the Literature. Sustainability 2020, 12, 1383.

46. Kawabe, M.; Kohno, H.; Ikeda, R.; Ishimaru, T.; Baba, O.; Horimoto, N.; Kanda, J.; Matsuyam, M.; Moteki, M.; Oshima, Y.; et al. Developing partnerships with the community for coastal ESD. Int. J. Sustain. High. Educ. 2013, 14, 122-132. [CrossRef]

47. Pedro, E.D.M.; Leitão, J.; Alves, H. Bridging Intellectual Capital, Sustainable Development and Quality of Life in Higher Education Institutions. Sustainability 2020, 12, 479. [CrossRef]

48. Stephens, J.C.; Hernandez, M.E.; Román, M.; Graham, A.C.; Scholz, R.W. Higher Education as a Change Agent for Sustainability in Different Cultures and Contexts. Int. J. Sustain. High. Educ. 2008, 9, 317-338. [CrossRef]

49. Ceptureanu, S.I.; Ceptureanu, E.G.; Bogdan, V.L.; Radulescu, V. Sustainability Perceptions in Romanian Non-Profit Organizations: An Exploratory Study Using Success Factor Analysis. Sustainability 2018, 10, 294. [CrossRef]

50. Drisko, J.W.; Maschi, T. Content Analysis; Oxford University Press: New York, NY, USA, 2016.

51. Adams, J.A.; Khan, H.T.A.; Raeside, R. Research Methods for Business and Social Science Students, 2nd ed.; Sage: London, UK, 2014.

52. Neuendorf, K.A. The Content Analysis Guidebook; Sage: Los Angeles, CA, USA, 2017.

53. Weber, R.P. Basic Content Analysis; Sage: Newbury Park, CA, USA, 1990.

54. Aslan, G. Öğretim Üyelerinin “Girişimci Üniversite” ve Üniversite Sanayi İşbirliği Kavramlarına İlişkin Görüşleri. Eğitim Bilim Toplum Dergisi 2010, 8, 7-22.

55. Lazzeretti, L.; Tavoletti, E. Higher Education Excellence and Local Economic Development: The Case of the Entrepreneurial University of Twente. Eur. Plan. Stud. 2005, 13, 475-493. [CrossRef]

56. Kang, S.; Na, Y.K. Effects of Strategy Characteristics for Sustainable Competitive Advantage in Sharing Economy Businesses on Creating Shared Value and Performance. Sustainability 2020, 12, 1397.

57. Mizruchi, M.S.; Fein, L.C. The social construction of organizational knowledge: A study of the uses of coercive, mimetic, and normative Isomorphism. Adm. Sci. Q. 1999, 33, 194-210. [CrossRef] 